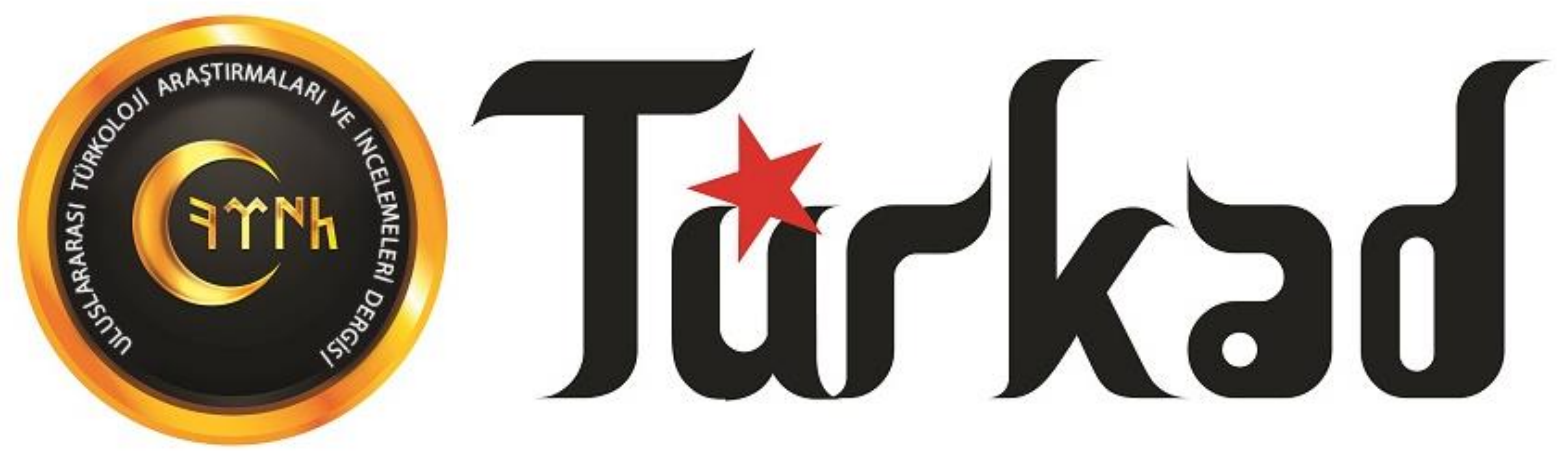

\title{
Yabancılara Türkçe Öğretiminin Temel Sorunları ve Bunlara Çözüm Önerileri
}

\author{
Mehmet KARA ${ }^{1} \&$ Eda ISSIR ${ }^{2}$
}

Özet

Yabancılara Türkçe öğretimi, kökenleri 11. yüzyıla dayandırılmakla birlikte akademik çalışmaların niceliği ve niteliği bakımından yeni ve gelişmekte olan bir alandır. Alanın akademik çalışmalarında, çeşitli sorunlarla karşılaşıldığı gözlemlenmiştir. Bu çalışmanın amac1; yabancılara Türkçe öğretimi alanyazınında sık karşılaşılan temel sorunları derleyip tespit etmek ve başlıklar altında incelemektir. Çalışmada nitel araştırma yöntemlerinden doküman incelemesi kullanılmıștır. Veriler alanyazın taraması yoluyla elde edilmiștir. Elde edilen veriler betimsel içerik analizi ile incelenmiştir. Yabancılara Türkçe öğretimi alanyazınında tespit edilen sorunlar, öğretici, öğrenici, öğretim programı, yöntemler, öğretim ortamı, kullanılan ders materyalleri ve alanyazın çalışmalarından kaynaklanan sorunlar şeklinde sekiz ana başlık altında toplanmıştır. Araştırma sonucunda bu sorunların çözümüne dair görüşler belirtilmiş ve birtakım öneriler sunulmuştur.

Anahtar Kelimeler: Yabancılara Türkçe öğretimi sorunları, sorunlar, çözüm önerileri.

\section{Basic Problems of Teaching Turkish to Foreigners and Proposals for Solutions}

\begin{abstract}
Teaching Turkish to foreigners is a new and developing field in terms of the quantity and quality of academic studies, although its origins date back to the 11 th century. . In academic studies of the field, various problems have been observed. The purpose of this study is to identify current issues that are common in the field of teaching Turkish to foreigners and to examine them under headlines. The study used document review from qualitative research methods. The data were obtained through literature review. The data obtained were examined through descriptive content analysis. The problems identified in the field of Turkish teaching to foreigners have been collected under eight main topics in the form of problems arising from the study of tutorial, learner, teaching program, methods, teaching environment, lecture materials used and related literature. As a result of the research, opinions have been made on solving these problems and a number of recommendations have been made.
\end{abstract}

Key Words: Problems teaching foreigners in Turkish, problems, solution proposals.

\footnotetext{
${ }^{1}$ Prof. Dr., Gazi Üniversitesi, fmkr48@gmail.com, 0000-0003-4691-5460.

2 Araş. Gör., Zonguldak Bülent Ecevit Üniversitesi, eda.isir@beun.edu.tr, 0000000213848698.
} 


\section{Giriş}

Dünya; başta ekonomik, siyasi, sosyolojik, kültürel olmak üzere her alanda sürekli bir etkileşim, değişim, dönüşüm ve gelişim içerisindedir. Bu sürecin neticesinde insanlar, kurumlar ve kuruluşlar arası etkileşim, her geçen gün daha da hızlanmış ve yabancı dil öğrenmeye olan ihtiyacı da artırmıştır. Bu durumun sonucu olarak yabancı dil öğreniminin ve öğretiminin daha hızlı, kolay ve nitelikli olması için birtakım akademik çalışmalar yapılmaya başlanmıştır. Bu konu yabancı dil olarak Türkçe öğrenimi ve öğretimi için de geçerlidir.

Türkçe, yaklaşık beş bin yıllık köklü geçmişi ve zengin söz varlığı ile tarih boyunca önemini koruyan dillerden biridir. Türkler, tarih sahnesinde geniş bir sahaya yayılmış, bu sahalarda birçok farklı toplumla ilişki içinde olmuştur. Bu duruma paralel olarak Türk dili de büyük bir coğrafyaya yayılmış; Asya, Avrupa, Afrika olmak üzere üç kıtada konuşulan ve yazılan bir dil olmuştur (Ergin, 2007). Geniş bir sahada konuşulan, içinde çok sayıda lehçe, şive ve ağız özellikleri barındıran Türkçe, çeşitli hedef kitlelere uzun yıllardır öğretilmektedir.

Türkiye, Doğu ve Batı arasında köprü görevi gören bir medeniyet merkezi olması nedeniyle farklı coğrafyalardan insanlara ev sahipliği yapmış, yıllar içinde bir çekim merkezi hâline gelmiştir. Bu bağlamda, dünya üzerinde Türkiye'yi ve Türkleri tanımak isteyenlerin sayısı gün geçtikçe artmakta, bir ülkeyi ve kültürü tanımanın en iyi yolu da o milletin dilini öğrenmekten geçmektedir (Başar \& Akbulut, 2016). Yabancılara Türkçe öğretimi alanı, Türkçe öğretiminin önemli bir dalı olarak mevcut gelişmeler ve ihtiyaçlar sonucunda ortaya çıkmıştır.

Yabancılara Türkçe öğretimi çalışmalarına tarihsel bir çizgide bakıldığında temellerinin oldukça eskilere dayandırıldığı görülmektedir. Alan çalışmalarında başlangıç olarak genellikle 11. yüzyılda Kâşgarlı Mahmud tarafından yazılan Dîvân-u Lugâti’t-Türk adlı eser kabul edilmektedir.

Dîvânu Lugâti't-Türk, Türkçe-Arapça bir sözlüktür. Türkçe sözlerin Arapça karşıllkları verildikten sonra mutlaka kelimelerin bağlam içinde kullanıldığı örnek bir cümle verilmiştir. Bu örnekler genellikle bir atasözü veya bir dörtlük olmuş; ardından kelimenin Arapça karş1lığ1 yazılmıştır. Örnek cümleleri ve açıklamalarıyla Dîvânu Lugâti't-Türk modern ve ansiklopedik bir sözlük gibidir (Ercilasun, 2004).

Karahanlı sahasında yazılan bu eserden sonra 13. yüzyılda Harezm ve Kıpçak sahasında yazılan Codex Cumanicus karşımıza çıkmaktadır. Codex Cumanicus, bir taraftan yabancılara Kıpçak Türkçesini öğretmeye çalışmak diğer yandan da Hıristiyanlık dinini Kıpçak Türkleri arasında yaymak için yazılmış pratik bir eserdir (Caferoğlu, 2000).

Çağatay sahasında ise 15. yüzyılda, iki dilin karşılaştırılması anlamına gelen "Muhâkemetü'l-Lugateyn" adlı eser Ali Şir Nevaî tarafından kaleme alınmıştır. Eserin yazılış amac1 Türk dilinin Farsçadan üstün olduğunu ortaya koymaktır. Nevaî̀ye göre Türkçe, söz varlığ1 ve dilbilgisi bakımından Farsçadan çok daha üstündür (Akar, 2005 akt. Çakmak, 2014). Çağatay sahasında kaleme alınmış olan sözlük-gramer kitabı başlığı altında Kitâb-1 Zebân-1 Türkî, Senglâh Lugati, El-Tamğa-yı Nâsırî, Feth-Ali Kacar Lûgati, Lugat-i Çağatay ve Türkî-i Osmanî adlı eserler de yer almaktadır.

Anadolu Sahasında ise Eski Oğuz Türkçesi ile kaleme alınan Hilyetül-İnsan ve Heybetül-Lisan adlı eser kaleme alınmıştır. "İnsanın Güzel Sifatları ve Dilin Büyüklüğ̈̈" anlamına gelen eserde günlük konuşma dilinden kelimelerin açıklamaları verilmiştir.

Osmanlı Devleti'nde de yabancılara Türkçe öğretimi olarak değerlendirilebilecek faaliyetler göze çarpmaktadır. Yeniçeri Ocağına katılan gayrimüslim çocukların, savaşlarda esir düşenlerin, devletin çeşitli kademelerinde çalıştırılmak üzere ailelerinden alınan 
devşirmelerin ve kendiliğinden Müslüman olanların Türkçe öğrenmesi için bazı çalışmalar yapılmıştır.

Osmanlı Döneminde birçok Avrupa devleti, ticari ve siyasi ilişkilerini geliştirmek için tercümanlar yetiştirmek amacıyla konuşma kılavuzları hazırlatmıştır. Ayrıca elçiliklerde çalıştırmak üzere yetiştirilen personellere yönelik Türkçe öğretimi kitapları hazırlanmıştır. Hatta akademik anlamda yabancı dil olarak Türkçe öğreten ilk kurumlar Batılıların öncülüğünde kurulmuştur denilebilir.

Avrupa'da XIII. yüzyılda yazılan Codex Cumanicus'tan sonra karşımıza çıkan Türkçe öğretimi ile ilgili ilk eser, Filippo Argenti'nin 1533 yılında hazırlamış olduğu Regola del parlare Turcho et Vocabulario de nomi et verbi (Türkçe Konuşma Kuralları ve İsim, Fiil Sözlükçesi) adlı kitaptır. Filippo Argenti'nin eseri XVI. yüzyılda Türkçe öğretimi ile ilgili yazılan tek eser olma niteliğine sahiptir. XVIII. yüzyılda Türkçe öğretimi üzerine yazılan eserlerin sayısı çoğalmaktadır. Bu dönemlerde Avrupa'da Latincenin akademik dil olarak kullanılmasından dolayı hazırlanan tüm eserler Latince açıklamalıdır. XIX. yüzyılın ilk yarısından itibaren ise Almanca, Fransızca, İngilizce ve Rusça açıklamalı Türkçe öğretimi kitapları hazırlanmaya başlamıştır. XX. yüzyıla gelindiğinde ise Almanca, Fransızca, İngilizce ve Rusçanın açıklamalı kitapların yanı sıra Macarca, İtalyanca, Romence, Çekçe, Bulgarca, Sırpça açıklamalı kitapların da yayımlandığını görmekteyiz. Nitekim, XIX. yüzyılda Avrupa'da hazırlanan Türkçe öğretimi kitaplarının çoğu İngilizce açıklamalı olmakla birlikte Makedonca, Felemenkçe, Bulgarca ve Yunanca açıklamalı kitaplar da mevcuttur. Hengirmen (1993, s. 9) XVII. yüzyıl ve XX. yüzyıl arasında Avrupa'da yabancilara Türkçe öğretimi konusunda 289 kitap yazıldığını belirtmektedir.

Yabanc1lara Türkçe öğretimindeki asıl atılım üniversiteler bünyesinde bulunan dil öğretim merkezlerinin (TÖMER, DİLMER, DEDAM, FÜSEM, HÜDİL vb.) açılması ile gerçekleşmiştir. Türk Dil Kurumu, Türk İşbirliği ve Kalkınma İdaresi Başkanlığı (TİKA), Türkiye Maarif Vakfı ve Yunus Emre Vakfının yabancılara Türkçe öğretimi alanında önemli çalışmalarda bulunmaları alanın gelişimi ve tanınmasına öncülük etmiştir. Son yıllarda hız kesmeden devam eden bu çalışmaların zenginliği ve verimliliği yabancılara Türkçe öğretimi alanında yazılan eserlere de yansımaktadır (Biçer, 2012 s. 16).

Türkiye'de 1950 yılından sonra üniversiteler bünyesinde Türkçenin yabancı dil olarak öğretimi sistematik bir biçimde yürütülmeye başlanmıştır. 1990’l1 yıllarda ise Türk soylu öğrencilerin ülkemize eğitim amacıyla gelmesi alandaki çalışmalara hız kazandırmıştır. Türkiye'deki üniversitelerin çoğunda alana dair lisansüstü programlar açılmakta ve TÖMER'ler ile yabancılara Türkçe öğretimi faaliyetleri sürdürülmektedir. Boylu ve Başar'in (2016) araştırmasında 2015 yılında Türkiye'deki mevcut TÖMER sayısı 85 olarak ifade edilirken Memiş’in (2021 s. 1) çalışmasında bu sayının 2018 yılında 126'ya ulaştığ tespit edilmiştir. Her yıl listeye yenileri eklenen TÖMER'ler ile günümüzde bu sayının arttığını ve artabileceğini söylemek mümkündür. Yabancılara Türkçe öğretiminde önemli rol oynayan kurumlardan biri de Yunus Emre Enstitüsüdür. Yurt dışında yer alan Türkoloji bölümleri ile Yunus Emre Enstitüsü tarafından açılan Türk Kültür Merkezleri, Türkiye dışında yabancı dil olarak Türkçenin öğretildiği kurumların başında gelmektedir. Bu kurumlarda eğitim, ticaret, turizm, aile birleşimi, eğlence vb. pek çok gerekçe ile binlerce birey yabancı dil olarak Türkçe öğrenmektedir (Başar ve Akbulut, 2016).

Sonuç olarak Türkçe ve Türk kültürüne olan ilginin gün geçtikçe artması, bu alandaki faaliyetlere olan ihtiyacı arttırmaktadır. Bu ihtiyaçlar doğrultusunda yabancılara Türkçe öğretimi faaliyetleri ülkemizdeki çeşitli kurumlar aracıllğı ile yürütülmekte ve ihtiyaçlar karşılanmaya çalışılmaktadır. Ancak söz konusu alanın yeni bir disiplin olmasından dolayı bazı sorunlarla karşılaşılmaktadır. Bu çalışmada, alanyazında sıkça söz edilen bu sorunlar başlıklar altında incelenmeye çalışılacaktır. 


\subsection{Araştırmanın Amacı}

$\mathrm{Bu}$ araştırmada yabancılara Türkçe öğretiminde karşılaşılan temel sorunlar başlıklar altında incelenmiştir. Bu kapsamda araştırmada aşağıdaki sorulara cevap aranmıştır:

1. Yabancılara Türkçe öğretiminde öğreticiden kaynaklı sorunlara dair bulgular nelerdir?

2. Yabancılara Türkçe öğretiminde öğreniciden kaynaklı sorunlara dair bulgular nelerdir?

3. Yabancılara Türkçe öğretiminde öğretim programından kaynaklı sorunlara dair bulgular nelerdir?

4. Yabancılara Türkçe öğretiminde öğrenme ortamından kaynaklı sorunlara dair bulgular nelerdir?

5. Yabancılara Türkçe öğretiminde alanyazından kaynaklı sorunlara dair bulgular nelerdir?

6. Yabancılara Türkçe öğretiminde öğretim materyallerinden kaynaklı sorunlara dair bulgular nelerdir?

7. Yabancılara Türkçe öğretiminde öğretim yöntemlerinden kaynaklı sorunlara dair bulgular nelerdir?

8. Yabancılara Türkçe öğretiminde kültür aktarımında karşılaşılan sorunlara dair bulgular nelerdir.

\section{Yöntem}

\subsection{Araştırmanın Modeli}

Yabancılara Türkçe öğretimindeki temel sorunların alanyazın çalışmaları çerçevesinde incelendiği bu çalışmada nitel araştırma yöntemlerinden doküman incelemesi kullanılmıştır. Nitel araştırma, gözlem, görüşme ve doküman analizi gibi nitel veri toplama yöntemlerinin kullanıldığı, olguların ve olayların doğal ortamda gerçekçi ve bütüncül bir biçimde ortaya konmasına yönelik nitel bir sürecin izlendiği araştırma olarak tanımlanabilir (Yıldırım ve Şimşek, 2008: 39). Bu yönüyle araştırma, alanyazında en çok yer bulan sorunları ifade etmeye gayret eden nitel bir çalışmadır.

\section{2. Çalışma Grubu}

Araştırmanın çalışma grubunu yabancılara Türkçe öğretimi alanında yazılan güncel sorunlara dair çalışmalar oluşturmaktadır. İncelenen çalışmaların seçilmesinde amaçlı örnekleme yönteminden yararlanılmıştır.

\subsection{Verilerin Toplanmas1 ve Analizi}

Araştırmada yararlanılan alanyazın çalışmalarından elde edilen verilerin değerlendirilmesinde nitel analiz tekniklerinden içerik analizi kullanılmıştır. İçerik analizinde temel amaç, toplanan verileri açıklayabilecek kavramlara ve ilişkilere ulaşmaktır. İçerik analizinde temelde yapılan işlem, birbirine benzeyen verileri belirli kavramlar ve temalar çerçevesinde bir araya getirmek ve bunları okuyucunun anlayabileceği bir biçimde düzenleyerek yorumlamaktır (Yıldırım \& Şimşek, 2008, s. 227). İnceleme sonucunda sıkça ifade edilen sorunlar başliklar altında ifade edilmiştir.

\subsection{Araștırmanın Önemi}

Yabancılara Türkçe öğretimi çokdisiplinli bir çalışma sahası olarak temelleri eskilere dayanmakla birlikte yeni bir alandır. Bu nedenle alanyazında yer alan çalışmalarda alanın sorun ve eksikliklerine yönelik tespitler göze çarpmaktadır. Söz konusu sorunlar öğrenici, öğretici, program, yöntem ve teknik, öğrenme ortamı ve ders materyallerinden kaynaklanan sorunlar gibi ana başl1klarda toplanabilmektedir. Bu araştırma, alanyazında sıkça ifade edilen sorunların başlıklar altında incelenmesi yönüyle benzer çalışmalardan farklılaşmaktadır. 
Çalışmanın sorun başlıklarına ilişkin daha net bir tablo ortaya koyarak alan araştırmacılarına 1şık tutması amaçlanmaktadır.

\section{Bulgular}

\section{1. Öğreticiden Kaynaklı Sorunlar}

Öğretim sürecinin önemli ögelerinin başında öğreticiler gelmektedir. Günümüzde benimsenen çağdaş yaklaşımlar, öğretimin merkezine öğreniciyi alsalar da her öğrenici, öğrenim sürecini etkili kılacak, kılavuzluk ve danışmanlık yapacak iyi bir öğreticiye ihtiyaç duymaktadir.

Ana dili eğitimi ekseninde öğretmen yeterliliği; alan bilgisi, meslekî yeterlilik ve genel kültüre hâkimiyet olmak üzere üç temel başlıktan oluşmaktadır. Yabancılara Türkçe öğretimi kapsamında ise öğreticilerin bu üç faktörün dışında sahip olması gereken ek yeterlilikler bulunmaktadır. Bu sahadaki öğretici temel olarak mesleki, kişisel ve pedagojik yeterliliklere sahip, bireysel ve kültürler arası farkl1l1klara saygılı, empati kurabilen, iletişime açık, temsil kabiliyeti yüksek, ana diline ve kültürüne hâkim bireyler olmalıdır. Kısacası öğreticinin beyin (kime, neyi, ne zaman ve kadar, nasıl öğreteceğini bilmesi), beden (dinç ve etkin olması) ve gönül (işini sevmesi) bütünlüğüne sahip olması gerekmektedir.

Durmuş (2019) öğretici yeterliliklerine ilişkin kültürel içeriklerin sunumunda başarıl1, pedagojik muhakeme becerisi ve karar verme kabiliyeti yüksek öğreticilere dikkat çekmiştir: Pedagojik muhakeme becerisi kısaca ögreticinin içerikle dilsel hedefleri tanımlayabilme, öğretim sürecinde uygun kararlar vermeye yönelik oluşabilecek sorunları ve bunların çözüm yollarını tahmin edebilme becerisi olarak tanımlanmaktadır. Deneyimli bir öğretici pedagojik muhakeme becerisini; her gün, derslerini ve derste kullanacağı materyalleri planlarken kullanabilmektedir.

Yabancı dil öğrenen bir kişi, hedef dile ait kültürün ve düşünce dünyasının da içine girmektedir. Bu bağlamda öğretici, kendi toplumunun ve dilinin kültürel kodlarını öğrenicilere gerekli ölçüde ve doğru bir şekilde sunabilmelidir. Bu nedenle öğretim sürecinde öğreticiler, sadece dil öğretiminden değil kültürel içeriklerin sunumu görevinden de sorumludur.

Öğreticilerin kültürel etkileşimi, öğrenicilerin toplumdan gelişigüzel edinmelerine bırakmadan doğru ve uygun bir şekilde gerçekleştirmesi, öğrenicilere güvenli, huzurlu, samimi ve motivasyon arttırıcı bir öğrenme ortamı sağlaması ve dersini etkili anlatabilmesi için iletişim becerilerini kullanabilmesi oldukça önemlidir. Bunu sağlamak için öğreticinin kendi kültürüne ve asgari düzeyde de olsa hedef kitlenin kültürüne hâkim olmasının etkili olabileceği düşünülmektedir. Yine öğreticilerin teknolojik gelişmelerin gerisinde kalması, öğrenme sürecini olumsuz etkileyen durumlardan biridir. Teknoloji ile iç içe yetişen yeni nesillere uyum sağlamakta zorlanan öğreticiler, kendilerini olabildiğince yenileyebilmeli ve süreç içinde dinamik olmaya özen göstermelidir.

İyi bir öğreticinin, hedef kitlenin seviyesine göre süreçte kullanılacak yöntem ve teknikleri süreç içinde belirleyerek öğretimin çerçevesini oluşturması oldukça önemlidir. Açık'ın (2008 s. 42) çalışmasında TÖMER'lerde görev yapan 100 öğreticiye farklı yöntem ve teknikleri kullanıp kullanmadığı sorulmuş ve katılımcıların \%44'ü kullandıklarını ifade etmişlerdir. Buna dayanarak öğreticilerin farklı yöntem ve teknik kullanımlarının arttırılması gerekli görülmektedir.

Öğretimin en önemli ayaklarından biri de ölçme değerlendirmedir. Öğreticilerin dil becerilerine, hedeflere, yöntem ve tekniklere, sürece ve içeriğe uygun ölçme ve değerlendirme araçlarını bilmesi ve bunları uygulayabilmesi çok önemlidir. Bu durum öğrenicinin dil öğrenme hızını, motivasyonunu ve derse olan bakışını çok etkilemektedir. 
Öğreticinin, çeşitli avantaj ve dezavantajları bünyesinde barındıran bu yöntemlerden yalnızca birini seçerek öğretim faaliyetlerinde bulunması doğru olmayacaktır. Balçıkanlı'ya (2021 s. 231) göre var olan yöntem ve yaklaşımlardan kendi bağlamına uygun olan yöntem ve tekniği seçerek eklektik bir yaklaşım sergilemeleri gerektiği söylenebilir. Öğreticilerin becerilere, yaşa, zamana, ortama göre uygun ölçme tekniklerini bilmesi ve süreç sonunda uygun ölçme araçlarını kullanması gerekir. Ancak öğreticilerin birçoğunun bu konulara vâkıf olmadığı ve bu eğitimi almadığı görülmektedir.

Ölçme ve değerlendirmenin de bir basamağı alan geribildirim, öğrenicilerin derse olan ilgisini, ciddiyetini ve öğrenme hızını artırmaktadır.

Öğrenme sürecinde önemli rollerden biri de geri bildirimlere düşmektedir. Geri bildirim, süreçte yazılı veya sözlü, anında veya sonradan verilebilen bir iletişim ögesidir. Dil öğretiminin bir etkileşim süreci olduğu düşünüldüğünde bu ögenin eksik olduğu bir iletişim düşünülemez. Bu nedenle öğreticilerin öğrenicilere farklı kanallarla beceriye uygun geri bildirim vermeleri öğretim sürecinin önemli bir parçasıdır. Öğreniciye bulunduğu seviye gözetilerek, en çok yapılan yanlıştan en az yapılan yanlışa doğru sıra izlenerek geri bildirimde bulunulmalıdır.

A1 düzeyinde geri bildirim vererek sık sık düzeltme yapılması yapılan sözlü ve yazılı yanlışların fazla olması nedeniyle öğrenicinin motivasyonunun azalması öğrenme sürecinde karşılaş1lan sorunlardan biridir. Burada öğrenicilerin dil yeterlik seviyesi gözetilerek yapıcı bir üslupla yorumlarda bulunulması oldukça önemlidir.

Öğreticilerin becerilere, yaşa, zamana, ortama göre uygun geribildirim tekniklerini bilmesi ve öğretim süreci boyunca bunları uygulaması gerekir. Ancak öğreticilerin birçoğunun bu konulara vâkıf olmadığı ve bu eğitimi almadığı görülmektedir.

Alanyazında öğreticilerin sahip olması gereken yeterlilikleri taşımasının ancak yeterli eğitim ve tecrübe ile sağlanacağ ifade edilmiştir. Son yıllarda alana olan ilginin artması ve alandaki öğretici sayısına olan ihtiyacın fazlalaşması nedeniyle Yunus Emre Enstitüsüne ek olarak üniversitelere bağlı TÖMER kurumları yabancılara Türkçe öğretimi sertifika programları açmaktadır. Programlarda, katılımcılar alanındaki uzman hocalardan teorik dersler almakta ve sertifika veren kurumun belirlediği ders saati kadar uygulama derslerine katılmaktadır. Bunun sonucunda uluslararası öğrencilere ders anlatma tecrübesini yaşayan katılımcilar sertifika almaya hak kazanmaktadır.

Ülkemizde 2020 Mart ayında ilk vakaya rastlanan COVID-19 salgını nedeniyle söz konusu sertifika çalışmaları da çevrim içi ortamlarda gerçekleştirilmeye başlanmıştır. Katılımcılar teorik dersleri seminerler yoluyla almakta, daha sonra çevrim içi bir şekilde derslere katılmakta ve çevrim içi yabancılara Türkçe öğretimi tecrübesi edinmektedir. Elbette, katılımcıların edindikleri bu tecrübeler yüz yüze eğitimde edinilecek tecrübeden oldukça farklıdır.

Temelleri yeni atılmış bir disiplinde bu tür eğitimler verilerek alana çalışmacılar kazandırılması oldukça kıymetli ve gereklidir. Ancak her iki durumdaki sertifika programlarının kısa süreli eğitimler olması, katılımcılardan bu programı alabilecek yeterliliğe sahip olup olmadıklarının tespit edilmemesi, eğitimlerin her TÖMER'de farklı ders saatleri ve içeriklerle verilmesi ve kalite farklarının ortaya çıkması, adayların uygulamalı ders anlatma sürelerinin genellikle bir iki ders saatiyle sınırlı olması, alınan sertifikanın yurt dışında veya farklı kurumlarda kabul görmemesi gibi önemli sorunlar da karşımıza çıkmaktadır (Memiş, 2021, 71-77). Gerek yüz yüze gerek çevrim içi yabancılara Türkçe öğretimi sertifika programlarının bu sorunlar göz önüne alınarak sorgulanması gerekmektedir. 
Öğreticiden kaynaklı sorunlarda değinilmesi gereken bir diğer eksiklik çocuk yaştaki ve özel eğitime ihtiyaç duyan öğrenicilere yönelik, öğreticilerin bilgi, tecrübe ve farkındalık düzeyinin düşük olmasıdır. Yabancılara Türkçe öğretimi kapsamında çocuk yaştaki ve özel gereksinimli bireyler için hem öğreticilerle hem de materyallerle ilgili henüz yeterli ve nitelikli çalışmaların yapılmamış olması alan için önemli eksikliklerdendir. Bu eksikliğin en büyük nedeni ise lisans eğitimi düzeyinde özel öğretime ihtiyaç duyan öğreticilere yönelik dersin verilmiyor olmasıdır. Bu eksiklikle yetişen öğretici adaylarının, dil öğretimi sürecinde özel eğitime gereksinim duyan bireylerle karşılaştıklarında çeşitli sorunlar yaşayacakları düşünülmektedir.

Öğreticilerden beklenen bu yeterliklerin sağlanabilmesi için elbette öğreticilerin eğitimine odaklanmak oldukça önemlidir. Yabancılara Türkçe eğitimi, ana dilinden farkl1 olarak, farklı hedef kitlelerle, farklı bağlamlarda ve farklı amaçlar doğrultusunda gerçekleştirilmektedir. Bu nedenle alanda hizmet verecek öğreticilerin bu alana ait bir lisans programından mezun olması gerekmektedir. Ancak bahsi geçen lisans programı henüz ülkemizde kurulmamıştır. Alana ait müstakil bir lisans eğitiminin verilememesi öğretici yeterliklerinin sağlanmasının önünde bir engel olarak varlığını sürdürmektedir. Özellikle Yabancılara Türkçe öğretimi derslerinin lisans eğitiminde ağırlığının arttırılması, Türkçe eğitimi lisans öğrencilerine TÖMER'lerde staj imkânının sağlanması, lisansüstü programların sayısının arttırılması ve ileriki süreçte lisans eğitiminin açılması alana katkı sağlayacaktır.

\section{2. Öğreniciden Kaynaklı Sorunlar}

Yabancılara Türkçe öğretimindeki hedef kitle, öğretimin yurt içinde veya yurt dışında yapılmasına göre çeşitlilik göstermekle birlikte Türkçe öğrenmek isteyen tüm bireylerdir. Yurt içinde Türkçe öğrenen hedef kitle zorunlu sebeplerle (savaş, göç, işsizlik vb.) veya eğitim amaçlı ülkemize gelen öğrenicilerden oluşmaktadır. Yurt dışında Türkçe öğrenen hedef kitle ise genellikle Türk diline olan bireysel veya çevresel yakınlıkları bulunan öğrenicilerden oluşmaktadır. Her iki öğrenici kitlesi içinde de yer alabilen Türk soylular ise Türkçe ve Türk kültürünün farklı sahalardaki devamlılığ için önem arz etmektedir. Bu iki farklı hedef kitle süreç başında ve süreçte farklı sorunlarla karşılaşabilmektedir.

Öğretim sürecindeki öğretici, öğretim programı, çevresel koşullar gibi ögeler ne kadar iyi olursa olsun öğrenici; fiziksel, zihinsel veya psikolojik olarak süreçte etkin değilse öğrenimin gerçekleşmesi zorlaşmaktadır. Öğreniciye ait sorunları; süreç başında ve süreçte karşılaş1lan sorunlar olarak ikiye ayırmamız mümkündür:

\subsection{1. Öğrenicilerin Süreç Başında Karşılaştığı Sorunlar}

Eğitim amaciyla Türkiye'ye gelerek TÖMER veya özel kurslarda eğitim alan öğrenicilerin yaşadıkları sorunların başında uyum sağlamada zorlanma ve hedef dil yetersizliğinden kaynaklanan iletişim sorunları gelmektedir. Kilometrelerce uzaklıkta, kültür ve dillerinden uzakta olan bireyler dil öğrenmeye yönelik kaygı yaşamaktadır. Bu öğrenciler genellikle Yurt Dışı Türkler ve Akraba Topluluklar Başkanlığı bünyesinde aldıkları burs imkânı sayesinde ülkemize gelerek eğitim almaktadır. Memiş $(2021$, s. 18) bu hedef kitlenin çoğunlukla Türkiye'den önce Avrupa ülkelerinden kabul almayı denedikleri, akademik başarı ve dil yeterliliği bakımından üst düzeyde bulunanların bu ülkelere giderken koşulları karşılayamayan öğrenicilerin ülkemizi tercih ettiklerini ifade etmiştir. Burada ülkemizin uluslararası öğrenci kabul etme koşullarının daha esnek olduğu, dil yeterliliğinin standart bir sınavla ölçülmediği sonucu çıkarılabilmektedir. Bu nedenle akademik başarısı ve dil yeterlik düzeyleri düşük olan bireylerin kendi dil ve kültüründe bile bir hazırbulunuşluğa sahip olmamas1, Türkiye'nin ve dolayısıyla Türkçenin genellikle ikinci planda tercih edilmesi sürecin başında veya süreç boyunca mücadele edilen önemli sorunların başında gelmektedir. Bu nedenle eğitim amacıyla ülkemize gelen öğrenicilerde belirli bir seviyede dil yeterliliği 
gözetilmesi ve öğrenci seçiminde daha titiz davranılması öğretim kalitesini olumlu yönde etkileyecektir.

Söz konusu öğrenicilerin özellikle ilk kez katıldığı ortamlarda (sınıf, sosyal çevre vb.) olumsuz tecrübeler edinmesi ise olumsuz bir tutum geliştirmelerine neden olabilmektedir. $\mathrm{Bu}$ aşamada, öğreticilere 1lımlı bir sınıf ortamı yaratma gibi önemli görevler düşmektedir.

Yurt dişında yani yaşadıkları ülkelerde Türkçe öğrenen öğreniciler genellikle dili kendi istekleri doğrultusunda öğrenmektedirler. Bu öğrenici kitlesinin bahsedilen uyum sorunlarını görece daha az yaşadıkları söylenebilir. Bu hedef kitlenin en önemli sorunu ise hedef dili yerinde öğrenmemekten kaynaklı olarak ana dili konuşurlarıyla iletişim imkânına daha az sahip olmalarıdır.

\subsection{2. Öğrenicilerin Süreçte Karşılaştığı Sorunlar}

Yabanc1lara Türkçe öğretiminde öğrenicilerin süreçte karşılaştıkları sorunlar hedef dile ilişkin öğrenme sorunlarıdır. Türkçeyi öğrenmeye çalışan öğreniciler dinleme, konuşma, okuma ve yazma becerilerinde ve dilbilgisi alanında öğrenim görmekte ve bu alanlarda çeşitli sorunlar yaşamaktadırlar. Öğreniciler, özellikle A1 ve A2 seviyelerinde anlama sorunları yaşamaktadır. Hedef dile ait söz dağarcığının henüz gelişmemiş olmasından kaynaklanan bu sorun, ilerleyen dönemde konuşma ve yazma becerilerini de olumsuz etkileyebilmektedir.

Türk soyluların yaşadıkları önemli sorunların başında ise özellikle Türkiye Türkçesi ile Türk lehçeleri arasında yazılışları aynı, anlamları farklı olan kelimeler ile ses ve biçim bakımından benzer olan eklerin farklı işlevlerde kullanılmasından kaynaklanan yani yalancı eşdeğerlilik durumu gelmektedir.

Konuşma ve yazma becerilerinde karşılaşılan sorunların başında ise hedef dil ve ana dili ailelerinin uzak oluşu ve alfabe farklılıklarından kaynaklı bazı seslerin çıkarılamaması veya bilinmemesi gelmektedir. Öğrenicilerin sosyal çevrelerinde ana dillerinde konuşması, TÖMER sınıflarında aynı dili konuşurlarının ortak sınıflarda olması gibi durumlar da hedef dil öğrenimi sürecinde olumsuz etki yaratabilmektedir. Yazma becerisinde ise bazı ünlü harflerin karıştırılması veya bilinmemesinden kaynaklanan yazım yanlışları ile karşılaşılmaktadır. Gelişimi uzun bir süreç isteyen bu iki beceride, hem öğreticinin hem de öğrenicinin sabırlı olması önem arz etmektedir.

Süreçte karşılaşılan bir başka sorun ise öğrenici kaygısıdır. Dil öğrenen insanlar kendilerini öğrendikleri dil ile birlikte her yönüyle farklı bir ortamda bulurlar. Bu durumu kendi kimliklerine ve benliklerine karşı bir tehdit olarak algılayabilirler. Böylece dil öğrenme heyecan verici olmaktan çıkarak korku ve kaygı unsuru olmaktadır (İşcan, 2016). Süreç başında ele alınan uyum sağlama sorunu, süreç içerisinde motivasyon eksikliği ve öğrenme kaygısı sorunları olarak karşımıza çıkmaktadır. TÖMER'lerde dil ve kültür bakımından heterojen sinıflarda ders verilmesi, anlama düzeyleri ve dile karşı hazırbulunuşlukları farklı olan bu bireylerde kaygıya neden olabilmektedir. Öğretim süreci boyunca öğrenicinin dil öğrenim sürecine karşı ilgi duymasını sağlamak; dile, kültüre ve bulunduğu ortama karşı olumlu tutum geliştirmesini amaçlamak, öğrenicilerin başarısı üzerinde oldukça önemlidir.

Öğrenici kaygısında önemli olan geçici kaygının sürekli kaygıya dönüşmesinin önüne geçebilmektir. Burada öğretici başta olmak üzere süreçte yer alan herkesin söz konusu kaygıyı azaltmak için gerekli çabayı göstermesi oldukça önemlidir.

\section{3. Öğretim Programından Kaynaklı Sorunlar}

Öğretim programları kısaca bir alandaki öğrenme ve öğretme etkinliklerinin planlanması olarak tanımlanabilir. Öğretim programları, oluşturduğu standartlar ve sağladığı birlik bakımından önem arz etmektedir. Öğretim programının sağladığı düzen, alanda ortak 
bir tutum ve bir birlik sağlamaktır. Durukan ve Maden (2013) yabanc1lara Türkçe öğretimine yönelik hazırlanan bir programın nitelikli olabilmesi için çerçeve niteliğinde olma, genellik ve değişmezlik, işlevsellik, esneklik, uygulanabilirlik, yenilenebilirlik, bilimsellik ilkeleri gözetilerek dört temel dil becerisi kapsamında hazırlanması gerektiğini ifade etmişlerdir.

Yabancılara Türkçe öğretimi, yıllardır öğretim faaliyetleri sürdürülen bir disiplin olmasına rağmen birleştirici bir nitelik taşıyan öğretim programının eksikliği günümüzde hâlâ hissedilmektedir. Ankara Üniversitesi Türkçe Öğretimi Uygulama ve Araştırma Merkezi tarafından 2015 yılında bir proje kapsamında yabancılara Türkçe öğretimi programı hazırlanmıştır. Ancak bu programın proje kapsamında kaldığı söylenebilir (Ankara TÖMER, 2015). Dolayısıyla Diller İçin Avrupa Ortak Başvuru Metni temelinde Türkçenin yabancı dil olarak öğretimine esas teşkil edecek, dil öğretim standartlarının belirlendiği bir öğretim programına olan ihtiyaç devam etmektedir.

Türkiye Maarif Vakfı 2019 yılında Türkçenin yurt dışında öğretiminde kullanılmak üzere bir öğretim programı hazırlamıştır. Bu program Diller İçin Avrupa Ortak Başvuru Metninde tanımlanan yeterlikler esas alınarak kademelere göre (A1-A2: Temel Dil Kullanım1, B1-B2: Bağımsız Dil Kullanımı C1: Yetkin Dil Kullanımı) hazırlanmıştır. Programın kazanım ve seviyelere göre uygun tekniklerle desteklenmesi, ders kitap setleri ve yardımcı materyallerin de hazırlanacak olması ve ölçme ve değerlendirme süreçlerinin tamamlanmış olması kapsamlı olması açısından önem arz etmektedir. Ancak söz konusu programın okul öncesi, ilköğretim I ve II. kademe ve ortaöğretim kademelerine yönelik hazırlanmış olması, üniversitelere bağl1 TÖMER kurumları veya Yunus Emre Enstitüsü bünyesinde, ileri yaştaki Türkçe öğrenicilerine yönelik ihtiyacı giderememiştir. Bu nedenle TÖMER'lere yönelik ortak bir öğretim programının eksikliği devam etmektedir. Bu noktada TÖMER'ler arasındaki öğretim farkl11ıklarına bağl1 akreditasyon sorunu merkeze alınarak ortak bir paydada, esnek bir program hazırlanmas oldukça önemlidir.

Yabancilara Türkçe Öğretimi kapsamındaki bir diğer sorun ise dil öğrenicilerin temel hedefleri (Türkiye'yi, Türk kültürünü tanımak, ticari işler yürütmek, akademik Türkçe öğrenmek, dil becerilerinden birini veya birkaçını geliştirmek vb.) ile bu hedeflere uygun zamansal (1, 3, 5, 6, 9 aylık) süreçlere göre hazırlanmış öğretim programlarının bulunmaması gelmektedir. Türkçe öğretimi yurt içinde genellikle üniversitelerin bünyesindeki TÖMER ve DİLMER'lerde; yurt dışında ise Yunus Emre Enstitüsüne bağlı Türk Kültür Merkezlerinde yapılmaktadır. Dolayısıyla bu programların Türkçe dil öğrenicilerinin yurt içinde ve yurt dışında Türkçe öğrenim görmelerine göre de değişiklik göstermesi gerekmektedir. Aynı programın hem yurt içinde hem de yurt dışında kullanılması birçok yönden uygun görülmemektedir (Memiş, 2021, 69-70). Hazırlanan programların bilgisi ve yetkisi olan otoriterlerce denetlenmesi ve akredite edilmesi gerekmektedir. Bu öğretim programı Diller İçin Avrupa Ortak Öneriler Çerçevesiyle uyumlu, açık ve anlaşılır olmanın yanı sıra güncellenebilen, süreç içinde var olan diğer öğelere rehberlik edebilecek özelliklere sahip olmalıdır. Bu alanlarda hazırlanacak nitelikli programlarla ölçme konusundaki sorunların da kısmen çözüme ulaşabileceği düşünülmektedir.

\section{4. Ölçme ve Değerlendirme Kaynaklı Sorunlar}

Yabancılara Türkçe Öğretimi alanında ölçünlü Türkçe yeterlilik ve düzey belirleme sınavları bakımından önemli bir boşluk söz konusudur (Durmuş, 2013). Bilimsel ölçütleri gözeterek Türkçe yeterliğini ölçen, uluslararası ve kurumlar arası ortak bir standarda sahip nitelikli bir sınavın olmaması, geçerlik ve güvenirliği olmayan sınavların yapılmasına, öğrenicilerin gerçek seviyesinin ölçülememesine, zaman ve hak kayıplarına neden olmaktadır (Memiş, 2021, s. 25). Bu ihtiyacın Yunus Emre Enstitüsü, öncü TÖMER’lerin, Yüksek Öğretim Kurumunun ve merkezî sinav sistemlerinin yürütüldüğü Ölçme, Seçme ve 
Yerleştirme Merkezi iş birliği ile giderilerek akredite edilmiş, ortak bir Türkçe yeterlik sınav sisteminin hazırlanması öğretim faaliyetlerinin sistematiği ve kalitesine katkı sağlayacaktır.

\section{5. Öğrenme Ortamından Kaynaklı Sorunlar}

Yabancılara Türkçe öğretimi kapsamında öğrenme ortamı kavramı genellikle TÖMER ve DİLMER sınıflarını ifade etmektedir. Bu kurumlarda farklı yaş, dil ve kültürlerden gelen öğreniciler dil ailesi benzerliklerine göre değil seviye tespit sınavlarına göre düzeylere ayrılmakta ve heterojen bir sınıf ortamında dil öğrenmektedir. Bu nedenle süreç içinde öğreniciler arasında özellikle bilişsel ve duyuşsal farklılıklar oluşabilmektedir. Özellikle Türkçeye ve Türk kültürüne daha aşina olan Türk soylular ile yabancı öğrenicilerin aynı sınıflarda öğrenim görmesi sürecin başında yabancı öğrenicilerde yetersizlik hissi yaratırken, ilerleyen dönemlerde Türk soyluların dile hâkim olduklarına dair rehavete kapılmalarına yol açabilmektedir. Bunun yanı sıra sınıfların kalabalık olması, öğrenicilerin süreçteki etkinliğine engel olabilmektedir. Özellikle konuşma ve dinleme derslerinde öğrenicilerin aktif olması ve sınıfın bu becerilere uygun şekilde düzenlenebilmesi önem arz etmektedir.

Öğrenme ortamının fiziksel olarak yeterli olmasının yanı sıra ortamın enerjisel olarak da pozitif bir atmosferde olması etkili bir akademik ortamın oluşmasını sağlamaktadır. Farklı yaşlarda, bireysel ve kültürel farklılıklar barındıran öğrenicilerin bulunduğu bir öğrenme ortamında 1lıman bir iklim yaratma görevi öğreticiye düşmektedir. Öğreniciler ile bu farkl11ıklara dikkat ederek iletişime geçebilmek, öğrenicilerin sosyalleşmesini ve kültüre uyum sağlamalarını gözetmek bu görevlerin başında gelmektedir.

Öğretim faaliyetlerinin gerçekleştiği ortamlara ülkemizde 2020 Mart ayı içerisinde görülen COVID-19 salgını nedeniyle çevrim içi öğrenme ortamları da eklenmiştir. Bunun yanı sıra yabancılara Türkçe öğretimi faaliyetleri ülkemizde genel olarak TÖMER ve DİLMER'ler ile özel kurslardaki sınıflarda gerçekleştirilmektedir. Er, Biçer ve Bozkırlı’nın (2012) çalışmasında eğitim öğretim ortamındaki yetersizliklere ilişkin eğitim öğretim ortamının teknolojiye ve dil öğretimindeki değişimlere göre yenilenmemesi ve öğretim ortamının değişik materyallerle zenginleştirilmemesine değinilmiştir. Özellikle dil öğrenme sürecinin sadece ders kitaplarıyla yürütülerek ek materyal kullanımının ihmal edilmesi konuşma ve dinleme gibi zengin içeriklerle desteklenmesi gereken becerilerin arka planda kalmasına yol açabilmektedir.

\subsection{Materyal Eksikliğinden Kaynaklanan Sorunlar}

Yabancılara Türkçe öğretiminde kullanılan materyaller öğretim sürecinde öğreticiye rehberlik etmesi nedeniyle ayrıca bir öneme sahiptir. Bu materyallerin taşıması gereken özellikler ana dili öğretimine yönelik hazırlanan materyallere göre farkl1lıklar göstermektedir.

Yabancılara Türkçe öğretimi dört temel dil becerisinin kazandırılmasına, dilbilgisi öğretimine ve kültür aktarımına dayanmaktadır. Bu öğretim sürecinin en önemli araçlarından biri de kullanılan ders kitaplarıdır. Ders kitapları, eğitim-öğretimin amaçlarını gerçekleştirmek üzere öğrencinin öğrenme yaşantılarına kaynaklık eden öğretim materyallerinden biri, hatta birçok durumda tek öğretim materyalidir (Halis, 2002). Yabanc1 dil öğretiminde en fazla kullanılan materyal basılı ders kitaplarıdır. Yabancılara Türkçe öğretimi alanyazınında ders kitapları üzerine yapılan çalışmaların sayıca fazla olması da bu görüşü desteklemektedir (Göçer, 2007; Caydaş, 2014; Karababa, 2012; Kara, 2017). Bu nedenle materyaller başlığını ders kitapları ve diğer materyaller olarak incelemek daha doğru olacaktır.

Ders kitapları başta olmak üzere yabancılara Türkçe öğretimine yönelik hazırlanan materyallerin amaca uygunluk ilkesine göre hazırlanması, dersin içeriğine ve kazandırılması hedeflenen beceriye yönelik uzman kişiler tarafından disiplinler arası bir çalışma ile hazırlanması gerekir. $\mathrm{Bu}$ alanda kullanılan materyallerin niteliğini belirleyen önemli 
faktörlerden bir diğeri ise hedef kitlenin hazırbulunuşluk/önbilgi düzeyidir. Yani temel Türkçe, orta Türkçe ve yüksek Türkçe düzeyinde kullanılan materyallerin türü ve içeriği farkl111k gösterir (Duman, 2013). Bu amaçla TÖMER'ler A1 seviyesinden C1 seviyesine kadar her seviye için farklı ders kitapları kullanmaktadırlar.

Yabancılara Türkçe Öğretimi özelinde bakıldığında ders kitaplarının TÖMER setleri veya bazı kişi ve kurumlar tarafından hazırlanmış kitaplar olduğu görülmektedir. Bu kitaplardaki eksikliklerin başında kitapların sadece örgün eğitime uygun olarak yapılandırılmış olması gelmektedir. Yani hazırlanan ders kitapları bir öğretim ortamı ve öğretici olmadan, bireysel olarak dili öğrenmeye uygun yapıda değildir.

İçinde bulunduğumuz küresel salgın nedeniyle yabancılara Türkçe öğretimi faaliyetleri çoğunlukla çevrim içi ortamlarda yürütülmektedir. Bu nedenle TÖMER’ler örgün eğitime yönelik hazırlanan ders kitabı setlerini $Z$ kitap versiyonunu kullanmaktadırlar. Ancak bir ders kitabını çevrim içi sisteme entegre etmekten ziyade çevrim içi sisteme yönelik yeni materyaller hazırlamak daha doğru ve daha kolaydır (Boylu, 2021). Bu nedenle değişen koşullara yönelik hazırlanacak materyallerin hedef kitlenin ihtiyaçları merkeze alınan, dijital ortama uygun, işlevsel ve öğrenmeyi zevkli hâle getiren materyaller olması gerekmektedir. Özellikle İngilizce öğretimi için çok sayıda mobil, web platformlarında kullanılan uygulamalar, e-kitaplar, dijital oyunlar gibi öğrenme materyalleri bulunmaktadır. Fakat yabancı dil olarak Türkçenin öğretiminde dijital platformlarda kullanılması için yapılan çalışmaların sayısı diğer dillerle karşılaştırıldığında oldukça azdır (Dündar ve Kara, 2019).

Bütün bunların yanı sıra bir öğreticinin hangi materyali ne zaman kullanacağını bilmesi, materyal hazırlama ve kullanma konusunda teknik donanıma sahip olması oldukça önemlidir. Kullanılan materyallerin tümleşik dil öğretimine uygun bir biçimde tasarlanması, hedef kitlede geriden gelen bir beceri varsa bu beceriye yönelik ek materyallere ağırlık verilmesi gerekmektedir.

Ders kitaplarındaki bir diğer sorun ise kitapta yer alan metinlerden kaynaklanmaktadır. Ders kitabında bulunan bir metin seçilirken öncelikle okunabilir/anlaşılabilir olması gerekmektedir. Bir metnin okunabilirliğinde metnin bilisssel yükü, uzunluğu, metindeki kelime sıklığı ve somut-soyut kelime yoğunluğu gibi belirleyiciler rol oynamaktadır. Örneğin A1 seviyesinde kelimelerin temel anlamda kullanıldığı metinler kullanılırken seviye ilerledikçe mecaz ifadeler barındıran kurmaca metinler ağırlık kazanmaktadır. $\mathrm{Bu}$ metinler hazırlanırken mutlaka sıklık ve derleme çalışmalarından yararlanarak her seviyeye farklı amaçla metinler hazırlanması gerekmektedir. Bu metni hazırlayacak yazar, editör ve dizgicinin yabanc1/ikinci dil öğretme bilinci ile hareket etmesi oldukça önemlidir.

Aynı bilinçle hareket edilmesi gereken noktalardan bir diğeri ise materyal aracılığı ile kültürel içeriklerin sunumudur. Yabancılara Türkçe öğretimi, Türkçenin yanında Türk kültürünün de öğretilmesine hizmet etmektedir. Dili öğretilen toplumun kültür ögelerinin öğrencilere gerekli ölçüde aktarılması ve öğretilmesi de büyük önem arz etmektedir (Barın, 2008 s. 61). Burada, kültürel içeriklerin sunumunun örtük bir şekilde gerçekleştirilmesi oldukça önemlidir.

Yabancılara Türkçe öğretimi materyali konusundaki bir başka sorun ders kitaplarının yanında kullanılan ek materyal eksikliğidir. Düzeylere ve amaçlara göre hazırlanmış çeşitli türdeki (eş, zıt, eş dizim, tematik, mesleki vd.) sözlük uygulamalarının ve seviyelere göre okuma setlerinin olmaması da önemli bir eksikliktir.

Sonuç olarak yabancılara Türkçe öğretimine yönelik hazırlanan ders kitapları başta olmak üzere tüm materyaller hedef kitlenin ihtiyaçlarına cevap verebilen, seviyelere uygun, dijital ortamlara da kolayca uyarlanabilen, kültür aktarımında başarılı, yaparak yaşayarak 
öğrenme ağırlıklı ve ilgi çekici materyaller olmalıdır. Materyaller alanında uzman akademisyenler, öğreticiler, dilbilimciler hatta halk bilimi uzmanlarının iş birliği ile hazırlanmalıdir.

\subsection{Alanyazından Kaynaklı Sorunlar}

Her yeni disiplinde olduğu gibi Yabancılara Türkçe öğretimi alanyazınında da bazı eksiklikler ve sorunlarla karşılaşılmaktadır. İlk olarak alanyazın çalışmalarında yabancılara Türkçe öğretiminin müstakil bir alan olarak amaçlarının net ve somut bir biçimde ifade edilememesi (Memiş, 2021, 6) önemli bir sorun olarak karşımıza çıkmaktadır.

Yabancılara Türkçe öğretimi alanyazın çalışmalarında ifade edilen amaçlar çoğunlukla dil eğitiminin genel amaçlarıdır ve Türkçe öğretiminin görünen yüzüdür. Akademik çalışma ve yayınlarda bu amaçların sürekli ve tekraren dillendirilmesi, alana ait gerçek hedeflerin neler olduğunun anlaşılması konusunda sorun oluşturmakta; amaçların somut ve açık bir biçimde ifade edilmesi ihtiyacını ortaya çıkarmaktadır (Memiş, 2021, s. 8). Alan amaçlarının net bir biçimde ortaya koyulması ihtiyaçların giderilmesine ve hedeflenen dil öğretimi çalışmalarının daha sistematik bir biçimde yürütülmesine olanak sağlayacaktır.

Alanyazındaki sorunlardan bir diğeri terminoloji sorunudur. Alandaki bazı kavramların kullanımında ortak paydada buluşulamaması alanyazın çalışmalarında anlam karmaşası yaratabilmektedir. Yabancılara Türkçe öğretimi alanyazınına bakıldığında ilk olarak alanın adına dair tartışmaların varlığı göze çarpmaktadır. Alan için "Yabancılara Türkçe Öğretimi, Yabancı Dil Olarak Türkçenin Öğretimi, Türkçenin Yabancı Dil Olarak Öğretimi ve Yabancı/İkinci Dil Olarak Türkçenin Öğretimi” gibi birbirinden farklı kavramlar kullanılmaktadır. Kullanılan bu başlıklar aynı amaçla kullanılsa da çeşitli tartışmalara yol açmaktadır. Özellikle yabancı dil ve ikinci dil tartışmalarında (Memiş, 2021, 34) Türkiye'de Türkçe öğrenen öğrenicilerin hedef dile maruz kalmaları dolayısıyla Türkçeyi ikinci dil (L2) olarak öğrendikleri savunulmaktadır. Durmuş (2021) bu ikilemi ortadan kaldıracak unsurun ortam olduğunu; hedef dil ana dili olarak konuşulan yerde öğretiliyorsa ikinci dil, ana dili olarak konuşulmadığı yerde öğretiliyorsa ise yabancı dil olduğunu belirtmiştir.

Alanın terminolojisinde ikilik yaratan bir diğer kavram ise öğrenici ve öğretici kavramlarıdır. Ana dili eğitimi çalışmalarında bu öğretmen ve öğrenci kavramlarına ilişkin bir belirsizlik söz konusu değildir. Çünkü söz konusu gruplar homojen gruplardır. Ancak yabanc1 dil ve ikinci dil çalışmalarında nitelik bakımından öğretmen ve öğrencilerde homojen bir hedef kitleden bahsetmek doğru değildir. Çünkü yabancı dil ve ikinci dil öğretimi yapan kişiler ana dili eğitiminde olduğu gibi ortak bir programdan mezun olup, mesleğe kabul edilip yine ortak bir öğretim uygulaması yürütmeyebilmektedir. Bu nedenle söz konusu hedef kitle için öğretici kavramının kullanıldığı görülmektedir. Yine dili öğrenen hedef kitlenin de yaş, dili öğrenme amac1 ve öğrenme hızı gibi standart özelliklerin bulunmaması öğrenici kavramının kullanılmasını gerektirmektedir (Durmuş, 2021, s. 136).

Alanyazındaki terminolojik sorunlar alanın uzmanları ve sorumlu kuruluşlarının ortak paydada buluşamamış olması nedeniyle varlığını sürdürmektedir. Söz konusu birliğin sağlanabilmesi için Türk Dil Kurumunun yabancılara Türkçe öğretimi alanında daha etkin rol almasının ortak bir paydada buluşmak adına önemli bir adım olacağı düşünülmektedir.

Yabancılara Türkçe Öğretimi alanyazınında ihtiyaç duyulan bazı akademik çalışmaların eksikliği bir diğer sorun olarak karşımıza çıkmaktadır. Sözlükler, sıklık ve derleme çalışmaları, okuma antolojileri ve çeşitli konularda yazılmasına ihtiyaç duyulan tez ve makaleler bunların başında gelmektedir.

Sözlükler bir dili esneklik, zenginlik, diğer dillerle olan ilişki ve etimoloji bakımından tanımlayan yazın eserleridir. McCarten (2007) bağlamdan hareketle öğretimin sözcük 
öğretiminde en etkili yol olduğunu belirtmektedir. Buradan hareketle hedef dilin öğretildiği sinıflarda bir sözcüğün anlamı hemen söylenmemeli, öğrencinin o sözcüğü metnin veya cümlenin bağlamından hareketle tahmin etmesi yoluna gidilmelidir. Böylelikle sözcüğün kalıcılık oranının yüksek olacağı düşünülmektedir (Göçer, 2007).

Öğrenicileri hedef alarak söz varlığını geliştirmeye yönelik hazırlanacak sözlüklerin özellikle uygulamada büyük bir yardımı olacağı düşünülmektedir. Bu çalışmalar yabanc1 öğreniciler için hazırlanmış sıklık ve derleme çalışmalarından hareketle yapılmalıdır. Hazırlanacak sözlüklerin içerisinde eş dizim sözlükleri, terim sözlükleri, eş ve zıt anlam sözlükleri, etimoloji sözlükleri, tematik sözlükler ve değerler sözlükleri yer almalıdır. Bu sözlüklerde sözcüklerin açıklamaları düzeylere göre sınıflandırılmalı ve olabildiğince açık şekilde tanımlanmalıdır. Hazırlanacak sıklık-derlem çalışmaları ve sözlükler ders kitapları başta olmak üzere alana yönelik materyallerin hazırlanmasını daha kolay ve sistematik hâle getirecektir. Bu nedenle sıklık ve derlem çalışmalarının geniş çaplı ve elektronik ortamda elde edilen verilerle sistematik bir biçimde yapılması gerekmektedir.

Alanda henüz okuma antolojilerinin bulunmaması ise başka bir alanyazın sorunudur. Antoloji konu ya da beğeniye göre derlenen metinlerin bulunduğu eserlere verilen addır (TDK, 2021 Erişim Tarihi: 30.03.2021). Yabancılara Türkçe Öğretimi kapsamında hazırlanması gereken okuma antolojileri öğretim ortamına göre yurt içinde ve yurt dışındaki yabancılara Türkçe öğretimi faaliyetlerine göre çeşitlilik göstermelidir. Öğretimin yapılacağı hedef kitleye göre ise iki dillilere, Türk soylulara ve yabancılara Türkçe öğretimi gibi her alan için ayrı antolojilerin hazırlanması gerekmektedir.

Yabancılara Türkçe öğretimi alanında yazılan tez ve makalelerin sayısının gün geçtikçe artması olumlu bir gelişme olarak görülmektedir. Ancak yazılan tez ve makalelerin genellikle aynı konularda ve aynı literatüre dayanarak yazılması, uygulamadan çok teorik konulara ağırlık verilmesi, uygulamalı çalışmalarda ise küçük örneklem grupları ile çalışılması önemli sorunlar (Memiş, 2021, 42-50) olarak karşımıza çıkmaktadır. Alanyazında yenilikçi görüşlerin ifade edildiği, yeni yöntemlerin literatüre kazandırıldığı, literatür zenginliğinin sağlandığı, uygulamaların büyük gruplarla yapılarak genelleme yapılabildiği çalışmalara olan ihtiyacın her zaman devam edeceği düşünülmektedir.

\subsection{Kültür Etkileşimi Sürecinde Karş1laşılan Sorunlar}

Günümüzde dünyanın farklı yerlerinden, Türkçeyi çeşitli sebeplerle yabanc1/ikinci dil olarak öğrenmek isteyenlerin sayısı gün geçtikçe artmaktadır. Türkiye'de ve Türkiye dışında yapılan yabancılara Türkçe öğretimi faaliyetleri Türkçe ile birlikte Türk kültürünü de öğretmeyi amaçlamaktadır.

Kültür etkileşiminin nasıl yapılması ve kültürel içeriklerin nasıl ve ne kadar sunulması gerektiğine dair sınırların çizilmemiş olması başlıca sorun olarak karşımıza çıkmaktadır. Kapsam alanı geniş olan kültür kavramını, yalnızca yiyecek-içecek, geleneksel kıyafet ve halk oyunlarıyla sınırlandırmamak gerekir. Kültürel etkileşim sürecinde dili öğrenilen toplumun düşünce yapısının da kavranması beklenir.

Yabanc1lara Türkçe öğretiminde kültürel etkileşim sürecine "ne kadar?" ve "nasıl?" soruları sorularak başlanmalıdır. Öncelikle kültürel içeriklerin tamamının öğretilemeyeceği bilinmeli ve sınırlar bu bilinçle çizilmelidir. Söz konusu sınırları çok geniş tutmanın dil öğrenme amacıyla Türkiye’ye gelen öğrenicileri olumsuz etkileyebileceği düşünülmektedir. Özellikle Türkçe öğrenme amacıyla ülkemize gelen öğreniciler toplum içinde dil ve kültür ile iç içedir. Bu nedenle sözü edilen hedef kitleye ilişkin kültürel etkileşim örtük ve günlük hayatta karşılaşılan durumları açıklayıcı şekilde yürütülmelidir. Yine çok kültürlü bir ortam olan sınıflarda, öğrenicilerin kültürleri kendi arasında veya Türk kültürü ile sürekli olarak 
kıyaslamak veya bir kültürü diğerine üstün göstermek yanlış olacaktır. Bu nedenle kültürler arasında ortak noktalara odaklanılmalı, kültürel benzerlikler ön plana çıkarılmalıdır.

Yabanc1lara Türkçe öğretiminde kültürel etkileşim başlığı altında karş1laşılan bir diğer sorun kullanılan materyallerdir. Materyallerin öğrenici düzeyine ve amacına uygun olmaması, kaynak kitapların içerikleri ve materyal çeşitliliğinin yeterli düzeyde olmaması, sık karşılaşılan sorunlar olarak karşımıza çıkmaktadır. Özellikle de kullanılan kaynak kitapların yurt içinde ve yurt dışındaki öğreniciler için ayrı ayrı hazırlanması önemlidir. Zira Türkiye'deki öğretim faaliyetleri için hazırlanmış kitapların yurt dışında kullanılması öğrenciler ve öğreticiler için tam olarak uygun değildir (Memiş, 2021, 104). Er, Biçer ve Bozkırlı (2012) öğrenicilerin ilgi ve ihtiyaçlarına uygun materyallerin kullanılmasının öğrenicilerin motivasyonunu arttırdığını ifade etmisslerdir.

Bunun yanında kültürel içerikler sadece ders kitaplarıyla verilmemektedir. Ders kitabındaki görseller, metin altı soruları, derste kullanılan ve kültürel kodlar barındıran filmler, şarkı ve türküler, bir restoranın menüsünde bulunan Türk yemekleri, kullanılan otantik metinler, atasözleri ve deyimler de kültürel etkileşime hizmet eden materyallerdendir. Yurt dışında yapılan Yabancılara Türkçe Öğretiminde öğreniciler ana dili konuşurları ile iletişim imkânı sınırlı olduğundan öğretici ve materyaller süreçte daha fazla rol oynamaktadır. Kullanılan ders kitaplarında kültürü yansıtıcı kodların verilmesinin yanında öğreticinin de bunu farklı uygulamalarla daha canlı hâle getirmesi sürecin verimini arttıracaktır.

Yabancılara Türkçe öğretiminde kültürel etkileşimi sağlayacak olan öncelikli olarak öğreticidir. Bu nedenle öğreticilerin hangi bölümlerden mezun olduğu, yabanc1 dil olarak Türkçe öğretimine dair sertifika ya da lisansüstü eğitimleri ve pedagojik formasyonlarının olup olmadığı, alan tecrübelerinin ve yeterliklerinin ne düzeyde olduğu mutlaka dikkate alınmalıdır. Bununla beraber öğreticilerin sadece yabancı dil ve kültürler hakkında da fikir sahibi olması gerekir. Çok kültürlü bir ortamda faaliyet gösteren öğreticiler bireysel ve kültürel farklılıklara saygılı, empati becerisi yüksek, gelişime, yeniliklere ve iletişime açık olmalıdır. Mesleki olarak sınıfta olumlu bir iklim yaratabilmeli, oluşabilecek beklenmedik krizleri önleyebilmeli ve kültürel kodları öğrenicilerine uygun bir biçimde sunabilmek için gerekli yeterliliklere sahip olmalıdır.

\section{Sonuç ve Öneriler}

Yeni bir disiplin olarak yabancılara Türkçe öğretimi alanında çeşitli sorunlarla karşılaşılmaktadır. Bu çalışmada alanda karşılaşılan sorunlar sekiz ana başlık altında incelenmiş ve şu sonuçlara ulaşılmıştır:

Öğretim sürecinde öğreticiden kaynaklı sorunlar arasında mesleki yeterlilik (alan, meslekî ve genel kültür), hedef dile ve kültüre hâkimiyet ve etkili iletişim ortamı kurmada zorluk gibi sorunlarla karşılaşılmaktadır. Elbette, bu alanda görev yapan öğreticiler, ana dili öğretici yeterliliklerine kıyasla ek donanımlara sahip olmalıdır. Öğretim sağladıkları hedef kitleyi, hedef kitleye ait dil ve kültürü tanımak bu yeterliklerin başında gelmektedir. Dersi bu bireysel farklı1ıkları gözeterek planlamalı, 11ımlı bir öğretim ortam oluşturabilmelidir. Ders kitapları başta olmak üzere alandaki materyalleri ve teknolojik donanımları etkin kullanabilmelidir. Yine beceri ve hedef kitle kesişimini dikkate alarak öğretim sürecinde kullanılacak yöntem ve tekniklere karar vermesi ve uygulama kabiliyetine sahip olması gerekmektedir. Çok kültürlü bir ortamda öğretim faaliyeti gerçekleştirilmesi nedeniyle kültürel farklılıkların bilincinde olmalı ve söz konusu farklılıklara saygı duymalıdır.

Yabancılara Türkçe öğretiminde öğrenicilere temel dil becerilerinde yetkinlik kazandırabilmek kadar kültür etkileşiminde bulunmak da önem arz etmektedir. Bu nedenle öğreticilerden hedef kültüre hâkim olması ve kültürler arasında özellikle Türk soylu öğreniciler söz konusu olduğunda farkl11ıklardan ziyade benzerliklere odaklanmaları 
beklenmektedir. Yurt dişında görev yapan öğreticilerin, öğrenicilerde hedef kültüre ilişkin farkındalık yaratmaları, öğreniciler bakımından önem arz etmektedir. Yabancılara Türkçe öğretimi kapsamında TÖMER'ler ve bazı özel kurslar tarafından verilen kısa süreli sertifika eğitimlerinin geliştirilmesi ve niteliğinin arttırılması öğretici kalitesinin devamlılığı açısından önemlidir.

Öğreniciden kaynaklı sorunlar başlığı bu çalışmada, süreç başında ve süreçte karșilașılan sorunlar olarak ikiye ayrılmıștır. Öğreniciler, süreç bașında hedef dil ve kültüre yönelik uyum sağlamada zorlanma ve hedef dil yetersizliğinden kaynaklanan iletişim sorunları yaşamaktadırlar. Süreçte ise bu sorunların devam edebildiği, ek olarak öğrenmeye ilişkin sorunların ortaya çıktığı görülmektedir. Dil becerilerinin gelişimi ve dilbilgisinin öğreniminde zorluk yaşadıkları gözlenen öğreniciler, dile karşı öğrenilmiş çaresizlik duygusuna kapılabilmekte ve kaygı durumları artmaktadır. Bu nedenle öğreticilerin olumlu bir sınıf iklimi oluşturabilmesi, öğrenici hatalarını uygun bir şekilde düzelterek beceri gelişiminin uzun bir süreç olduğunu vurgulaması oldukça önem arz etmektedir.

Program ögelerinden biri olan ölçme aşamasında ise ölçme işlemini gerçekleştirecek kurum ve ekiplerin özellikle geribildirim konusunda yapacağı çalışmalar oldukça önemli olacaktır.

Yabancılara Türkçe öğretiminde ortam faktörü birden fazla anlam ifade edebilmektedir. Bunlardan ilki hedef dil öğretiminin gerçekleştiği bağlamdır. Ülkemizde 2020 Mart ayı içerisinde görülen COVID-19 salgını nedeniyle çevrimiçi öğrenme ortamlar da öğretim faaliyetlerindeki önemini arttırmıştır.

Dil öğretiminin Türkiye'de ve Türkiye dişında yapılması ise öğrenme ortamı kavramının ikinci boyutunu oluşturmaktadır. Hedef dili o ülkede öğrenen öğrenicilerin öğrenmeyenlere göre daha hızlı yol kat etmekte oldukları yapılan çalışmalarda görülmektedir. Öğrenicilerin öğrendiklerini uygulama alanının bulunması öğrenme sürecini hızlandıran unsurların başında gelmektedir. Bu durum bir dezavantajdan ziyade dil öğretim ortamlarının çeşitli olmasıdır. Bu nedenle her iki hedef kitlenin ihtiyaçları ve dil öğrenim süreçleri birbirinden farklıdır.

Yabancılara Türkçe öğretimi alanında kullanılan materyaller ise alanda sıkça ifade edilen sorunlardan biridir. Öğretim materyalleri denilince akla ilk gelen basılı materyallerden ders kitaplarıdır. Yabancılara Türkçe Öğretiminde hazırlanan ders kitapları TÖMER'lerin kendi bünyesinde süreç içerisinde kullanılmak için hazırlamış oldukları materyallerdir. $\mathrm{Bu}$ kitapların yanında bireylerin kendi kendine öğrenmesi (self learning) sürecine uygun olarak hazırlanan kitaplar oldukça azdır. Hazırlanan tüm materyaller bir öğretim ortamı ve öğreticinin olduğu ortamlar için tasarlanmaktadır.

Ders kitabına alınan metinlerde ise açıklık, anlaşılırlık, okunabilirlik, seviyeye ve amaca uygunluk ilkeleri gözetilmekte fakat bazı metinler bu özelliklerin bazılarını barındırmamaktadır. Bunun yanında metinler aracılığıyla sunulan kültürel içeriklerin örtük bir şekilde sunulması gerekmektedir. Söz konusu metinler üzerinde cümleleri parçalama, kelime atımı/değişimi yapma, genişletme, sadeleştirme ve özetleme yöntemleri kullanarak metnin bilişsel yükü hafifletilip düzeylere uyarlanabilmelidir.

Yabancılara Türkçe Öğretimi alanındaki alanyazın sorunlarında sıklık ve derlem çalışmaları, alan için seviyelere göre özel hazırlanması gereken tematik, etimolojik, değerler ve eş dizim sözlükleri, okuma antolojilerin azlığı veya eksikliği önemli sorun başlıklarındandır. Bahsi geçen sözlükler sıklık ve derlem çalışmalarından hareketle seviyelere göre ayrı ayrı hazırlanmal1, okuma antolojileri ise alanında uzman kişilerin oluşturduğu bir heyet tarafından oluşturulmalıdır. Yapılacak bu çalışmalar alandaki boşlukların doldurulmasına 
yardımcı olacaktır. Çalışmalarda alan adı olarak aynı ismin kullanılmasının da bu terminolojik belirsizliği ortadan kaldıracağı düşünülmektedir.

Yabanc1lara Türkçe öğretiminde öğretim sürecinde geleneksel dil öğretme yöntemlerinin yanında yansıtıcı öğretim gibi çağdaş yöntemlerin daha az tercih edilmesi ise önemli bir eksiklik olarak görülebilir. Bu nedenle süreç içinde farklı yöntem ve tekniklerin kullanılmasının verimliliği arttıracağı düşünülmektedir.

Yabancılara Türkçe öğretimi faaliyetleri dil becerilerinde yetkinlik sağlamanın yanı sıra kültür etkileşimini amaçlamaktadır. Öğrenim sürecinde kültür etkileşiminin sadece ders kitaplarındaki metinlerle gerçekleştirildiği düşünülmemelidir. Öğreticinin model olması, öğretim ortamında kullanılan otantik bir metin, dinleme metni olarak kullanılan bir şarkı veya türkü de kültürel etkileşime hizmet etmektedir. Burada dikkat edilmesi gereken en önemli nokta etkileşimin örtük bir biçimde gerçekleştirilmesidir. Hedef kültür, açık ve baskın bir biçimde veya somut-soyut, yazıl1-sözlü kültürü yoğun bir biçimde verilmeye çalışıldığında ögreniciler üzerinde olumsuz bir etkiye neden olabilmektedir. Bu nedenle öğretim sürecinde kullanılan materyaller, bu materyallerin hazırlanmasında rol oynayan akademisyenler ve bu materyalleri kullanan öğreticiler kültürlerarası kıyaslama yerine kültürel ortaklık üzerinden öğretim gerçekleştirmelidir.

\section{Kaynakça}

Açık, F. (2008). Türkiye'de yabancılara Türkçe öğretilirken karşılaşılan sorunlar ve çözüm önerileri. Uluslararası Türkçe Eğitimi ve Öğretimi Sempozyumu. Doğu Akdeniz Üniversitesi Eğitim Fakültesi. Mayıs 2008. Kuzey Kıbrıs Türk Cumhuriyeti.

Ankara TÖMER. (2015). Yabancilara Türkçe öğretimi öğretim programı. http://tomer.ankara.edu.tr/ adresinden erişildi. (Erişim Tarihi: 14.03.2021)

Balçıkanlı, C. (2021). 50 soruda dil öğrenme. İstanbul: Bilim ve Gelecek Kitaplığı.

Barın, E. (2008). Yabancılara Türkçe öğretiminde Nasreddin Hoca fikralarının yeri, Türk Yurdu, 255, 61-63.

Başar, U. ve Akbulut, E. (2016). Yabancılara Türkçe öğretiminde öğrenen ihtiyaçlarının belirlenmesi: Yunus Emre Enstitüsü Tiflis Türk kültür merkezi örneği. Uluslararası Türkçe Edebiyat Kültür Eğitim Dergisi, 5(2), 1005-1020.

Biçer, N. (2012). Hunlardan günümüze yabanc1lara Türkçe öğretimi. Uluslararası Türkçe Edebiyat Kültür Eğitim (TEKE) Dergisi, 1(4), 107-133.

Boylu, E. (2021). Soru ve cevaplarla yabancı dil olarak Türkçe öğretimi el kitabı. Ankara: Pegem Akademi.

Boylu, E. ve Başar, U. (2016). Türkçe öğretim merkezlerininin güncel durumu ve standartlaştırılması üzerine. Akademik Sosyal Araştırmalar Dergisi, 4(24), 309-324.

Caferoğlu, A. (2000). Türk dili tarihi I-II, İstanbul: Enderun Kitabevi.

Çakmak, C. (2014). Yabancılara Türkçe öğretiminin tarihçesine genel bir bakış denemesi. 4(2). 122-131.

Çaydaş, A. (2016). Gazi Üniversitesi TÖMER ve İzmir yabanc1lar için türkçe öğretim setlerinde kullanılan kalıp sözlerin incelenmesi. Nevşehir Hacı Bektaş Veli Üniversitesi. Yayımlanmış Yüksek Lisans Tezi.

Duman, G. B. (2013) Türkçenin yabancı dil olarak öğretiminde materyal geliştirme ve materyallerin etkin kullanımı. Ana Dili Eğitimi Dergisi, 1(2), 1-8. 
Durmuş, M. (2013). Türkçenin yabanc1lara öğretimi: sorunlar, çözüm önerileri ve yabancılara Türkçe öğretiminin geleceğiyle ilgili görüşler. Adıyaman Üniversitesi Sosyal Bilimler Enstitüsü Dergisi, 2(11).

Durmuş, M. (2019). Dil Öğretiminde öğretici yeterlilikleri ve pedagojik muhakeme becerisi. İstanbul: Grafiker Yayınları.

Durukan, E. ve Maden, S. (2013). Yabancılara Türkçe öğretimi programı geliştirme. Ankara: Grafiker Yayınları.

Dündar, Ş. ve Kara, M. (2019). Yabancı dil olarak Türkçenin öğretiminde dijital platformların kullanılmasına yönelik öğretmenlerin görüşleri. 21. Yüzyılda Eğitim ve Toplum Eğitim Bilimleri ve Sosyal Araştırmalar Dergisi, 8 (24) , 557-579.

Er, O., Biçer, N. ve Bozkırlı, K. (2012). Yabancılara Türkçe öğretiminde karşılaşılan sorunların ilgili alan yazını ışığında değerlendirilmesi. Uluslararası Türkçe Edebiyat Kültür Eğitim (TEKE) Dergisi, 1(2), 51-69.

Ercilasun, A. Bican (2005). Başlangıçtan yirminci yüzyıla Türk dili tarihi, Ankara: Akçağ Yayınları.

Ergin, M. (2009). Türk dili. İstanbul: Bayrak Yayınları.

Göçer, A. (2007). Türkçenin yabancı dil olarak öğretiminde kullanılan ders kitaplarının ölçme ve değerlendirme açısından incelenmesi. Gazi Üniversitesinde 22- 23 Kasım 2007 tarihleri arasında düzenlenen Türkiye'de Yabancı Dil Eğitimi Ulusal Kongresinde sunulmuştur.

Halis, İ. (2002). Öğretim teknolojileri ve materyal geliştirme. Ankara: Nobel Yayınları.

Hengirmen, M. (1993). Türkçenin yabanc1 dil olarak öğretimi. AÜ TÖMER Dil Dergisi, (10), 59.

İşcan, A. (2016). Yabanc1 dil olarak Türkçe öğretiminde yabanc1 dil kaygısının Türkçe öğrenenler üzerindeki etkisi (Ürdün Üniversitesi örneği). Dil ve Edebiyat Eğitimi Dergisi, (17), 106-120.

Kara, M. (2017). Türkçenin yabancı dil olarak öğretiminde kullanılan ders kitaplarında metinler arası aşamalılık: Yedi iklim Türkçe ve İzmir üzerine karşılaştırmalı bir inceleme. Bartın Üniversitesi Eğitim Fakültesi Dergisi, 6(2), 411-426.

Karababa, C. (2012). Yabancı dil olarak Türkçe öğretiminde kullanılan ders kitaplarının öğretmen görüşleri çerçevesinde değerlendirilmesi. Dil Dergisi, 157.

Maden, S. (2015). Türkçeyi yabancı dil olarak öğrenenlerin yazma kaygıları. Uluslararası Türkçe Edebiyat Kültür Eğitim Dergisi, 4(2), 748-769.

McCarten, J. (2007). Teaching vocabulary lessons from the corpus, lessons for the classroom. Cambridge University Press.

Memiş, M. (2021). Yabancılara Türkçe öğretiminin güncel sorunları. Ankara: Pegem Akademi.

Türkiye Maarif Vakfi. (2019). Türkçenin yabanc1 dil olarak öğretimi programı. https://turkiyemaarif.org/page/524-Turkiye-Maarif-Vakfi-12 adresinden erişildi. (Erişim Tarihi: 01.06.2021).

Yıldırım, A. ve Şimşek, H. (2008). Sosyal bilimlerde nitel araştırma yöntemleri. Ankara: Seçkin Yayınları. 